\title{
Relationship Between Immunization Status and Stunting in Toddler aged 2 - 5 Years in Banjarejo Village
}

\author{
Khaula Salsabilla Nur Achmad ${ }^{\mathrm{a}}$, Nining Febriyana ${ }^{\mathrm{b}}$, Widati Fatmaningrum ${ }^{\mathrm{c} *}$ \\ ${ }^{\mathrm{c}}$ widatifatmaningrum@yahoo.com \\ ${ }^{\text {a}}$ Faculty of Medicine, Universitas Airlangga Jl. Mayjen Prof. Dr. Moestopo No.47, Surabaya 60131, Indonesia \\ ${ }^{b}$ Department of Mental Health, Faculty of Medicine, Universitas Airlangga, J1. Mayjen Prof. Dr. Moestopo No.47, Surabaya 60131, \\ Indonesia \\ ${ }^{\mathrm{C}}$ Department of Public Health, Faculty of Medicine, Universitas Airlangga, J1. Mayjen Prof. Dr. Moestopo No.47, Surabaya 60131, \\ Indonesia
}

\begin{abstract}
Indonesia is one of the countries ranked in the top ten countries with a high stunting rate in Southeast Asia with a stunting rate of 36.4\%. (WHO, 2019). Banjarejo village has a stunting prevalence of $39.3 \%$ in February 2021. Immunization status is one of many factors that influences stunting. The objective of this study is to analyze the relationship between immunization status and stunting in toddlers aged 2 to 5 years in Banjarejo Village. A quantitative research approach with a Cross-Sectional design was conducted in Banjarejo Village with a sample of 84 toddlers. The data collected includes primary data and secondary data. Data analysis included univariate and bivariate using Chi-square test at $95 \%$ CI. The results of this research are there is no relation between immunization status and stunting in toddler aged 2-5 years in Banjarejo Village.
\end{abstract}

Keywords: Immunization Status; Stunting

\section{Introduction}

Stunting is a major nutritional problem faced by Indonesia. According to the Pemantauan Status Gizi (PSG)'s data in 2017, short toddlers have the highest prevalence. Stunting is a latent problem. It depicts a chronic malnutrition during a child's growth since birth (Ni'mah \& Nadhiroh, 2015). The highest stunting rates occur in Southeast Asia and Africa. Indonesia is one of the countries ranked in the top countries with a high stunting rate in Southeast Asia with a stunting rate of $36.4 \%$ (WHO, 2019).

Stunting has a major impact on the quality of health, intellect, and productivity in the future (USAID, 2014; Kemenkes, 2013). Immunization is an effort to actively induce/increase a person's immunity to a disease so that if one day they are exposed to the disease, they will not get sick or only experience mild illness (Kemenkes RI, 2013). Immunization has a goal to reduce the risk of morbidity (illness) and mortality (death) of children due to diseases that can be achieved by technique (Liliana, 2006). Disease gives negative 
feedback to the nutritional status and if it happens over a long time it can increase the risk of stunting (Permatasari \& Sumarmi, 2018).

From the several sources above, immunization status is one of factor influencing the increase in stunting. So based on some of the explanations and sources above, this research is aimed to analyze the relationship between immunization status and stunting in toddlers aged 2 to 5 years in Banjarejo Village.

\section{Research Elaboration}

The research design used by the researcher was analytic observational with cross-sectional design. This study aims to determine the relationship between immunization status and stunting in toddlers aged 2 to 5 years. This research was conducted in May 2020-June 2021. This research was carried out in Banjarejo Village. Respondents obtained as many as 84 toddlers with a total random sampling method sampling technique by the inclusion and exclusion criteria.

Inclusion criteria for children aged two to four years old in this study included: Toddlers who live in Banjarejo Village that weighed and measured height at the Sumberaji Health Center, Toddlers aged 2 to 5 years, and respondents who had KIA books. The exclusion criteria for toddlers in this study are children with a history of chronic illness.

The independent variables of this study were immunization status which was collected through questionnaires from the ministry of health, interviews, and KIA books. The dependent variable of this study is the incidence of stunting in toddlers aged 2 to 5 years which is secondary data from the results of measurements by local health workers. The results of the measurement of toddlers are categorized as stunting toddlers if Z-score < -2 SD and normal toddlers if Z-Score -2 SD. The results of this study were analyzed bivariately using chi-square. This research was also ethically approved by the Ethics Committees of Medicine Faculty of Universitas Airlangga, Surabaya.

\section{Results and Discussions}

The purpose of the univariate analysis is to explain or describe the characteristics of each variable studied, where this analysis was carried out on each research variable made using a frequency distribution table.

Table 1. Toddlers Gender Profile

\begin{tabular}{lccc}
\hline & Variable & n & $(\%)$ \\
\hline Gender & & \\
Male & 46 & 54.8 \\
Female & 38 & 45.2 \\
Total & 84 & 100 \\
\hline
\end{tabular}

Based on table 1, most of the toddlers are male. The percentage of male toddler $(54.8 \%)$ are more than the female toddler $(45.2 \%)$. 
Table 2. Toddlers Gender Profile

\begin{tabular}{lcc}
\multicolumn{1}{c}{ Variable } & $\mathbf{n}$ & $(\boldsymbol{\%})$ \\
\hline Age & & \\
$2-3$ years & 32 & 38.1 \\
4- 5 years & 52 & 61.9 \\
Total & 84 & 100 \\
\hline
\end{tabular}

Based on table 2, most of the toddlers are aged 4-5 years. The percentage of 2-3 years old toddlers is $(38.1 \%)$ while the $4-5$ years old toddlers is $(45.2 \%)$.

Table 3. Toddlers Current Weight Profile

\begin{tabular}{lll}
\multicolumn{1}{c}{ Variable } & n & $(\%)$ \\
\hline Current Weight & 32 & 39.3 \\
$8-12 \mathrm{~kg}$ & 52 & 60.7 \\
$13-16 \mathrm{~kg}$ & 84 & 100 \\
Total & & \\
\hline
\end{tabular}

Based on table 3 , most of the toddlers are weight $13-16 \mathrm{~kg}$. The percentage of toddlers weight $8-12 \mathrm{~kg}$ is $(39.3 \%)$ while the toddlers weight $13-16 \mathrm{~kg}$ is $(60.7 \%)$.

Table 4. Toddlers Immunization Status Profile

\begin{tabular}{lcc}
\multicolumn{1}{c}{ Variable } & n & $(\boldsymbol{\%})$ \\
\hline Immunization Status & 5 & 6.0 \\
Not Complete & 79 & 94.0 \\
Complete & 84 & 100 \\
Total & 54 & \\
\hline
\end{tabular}

Based on table 4 , most of the toddlers are having a complete immunization status. The percentage of toddler with incomplete immunization only $(6.0 \%)$ while the toddlers with complete immunization status is $(94 \%)$.

Table 5. Toddlers Nutritional Status Based on TB/U Profile

\begin{tabular}{lcc}
\multicolumn{1}{c}{ Variable } & n & $(\boldsymbol{\%})$ \\
\hline Nutritional Status TB/U & & \\
Very Short & 12 & 14.3 \\
Short & 22 & 26.2 \\
Normal & 42 & 50.0 \\
High & 8 & 9.5 \\
Total & 84 & 100 \\
\hline
\end{tabular}

Based on table 5, most of the toddlers are having a normal nutritional status. The percentage of toddler with incomplete immunization only (6.0\%) while the toddlers with complete immunization status is $(94 \%)$.

Table 6. Relation of Immunization Status with Stunting

\begin{tabular}{|c|c|c|c|c|c|}
\hline \multirow{3}{*}{ Variable } & \multicolumn{4}{|c|}{ Stunting Incidence } & \multirow{3}{*}{ p valu-e } \\
\hline & \multicolumn{2}{|c|}{ Yes } & \multicolumn{2}{|c|}{ No } & \\
\hline & $\mathbf{n}$ & $(\%)$ & $\mathbf{n}$ & $(\%)$ & \\
\hline Not Complete & 2 & 2.4 & 3 & 3.6 & \multirow[b]{2}{*}{0.973} \\
\hline Complete & 31 & 36.9 & 48 & 57.1 & \\
\hline
\end{tabular}

Based on table 6 , the results showed that the majority of children aged 2-5 years received complete 
immunization. Some children still experience stunting even after they got a complete immunization. After the chi-square test with a significant level of $5 \%$, it was found that the p-value is 0.973 which means $\mathrm{p}$ value > 0.05 , so there is no relationship between immunization status and the incidence of stunting in Toddlers aged 2-5 years with a correlation coefficient of 0.001 .

The results of this study are not in accordance with Arianto's research which states that there is a significant relationship between immunization basic with nutritional status of children under five with $p$ value $=0.014$. Rahmad, et al (2013) stated that if toddlers do not have immunity to disease, the toddler will be faster lose of body energy due to illness infection, as the first reaction due to infection is a decrease in the child's appetite so that the child refuses food that is given by his mother.

But the results of this study are in line with research conducted by Kasim, et al (2019) who found that there was no relationship between the immunization status and the nutritional status of children aged 24-59 months according to the anthropometric index of BB/U, TB/U, and BB/TB. Immunization affects the child's infection rate and can later be related to the child's nutritional intake. The infection rate is not only determined by the immunization status. Environment sanitation also plays a big role as the promotor of infection rates in toddlers. Even if a toddler has a complete status of immunization but the environment sanitation is not proper, there is still a chance a toddler got infected. Immunization in this study was not related to the incidence of stunting because apart from being influenced by the completeness of immunization, there are several other factors that can affect the toddler's height, namely: hereditary factors, prenatal environmental factors, and postnatal environmental factors.

\section{Conclusion}

The prevalence of stunting in Indonesia is high at $36.4 \%$. There is no relationship between immunization status and stunting in toddlers aged 2 to 5 years in Banjarejo Village.

Mothers who have children under five should be able to pay attention for their environmental sanitation. Health institutions are expected to increase counseling about stunting and how to maintaining environmental hygiene, especially at the posyandu level. The community is expected to pay close attention to the cleanliness and health of the environment.

\section{Acknowledgments}

Acknowledgments to the Faculty of Medicine of Universitas Airlangga.

\section{Reference}

Al-Rahmad, A. H., Miko, A., \& Hadi, A., 2013. Kajian stunting pada anak balita ditinjau dari pemberian ASI eksklusif, MP-ASI, status imunisasi dan karakteristik keluarga di Kota Banda Aceh. J Kesehatan Ilmiah Nasuwakes, 6(2), p. 169-184.

Anisa, P., 2012. Faktor-Faktor Yang Berhubungan Dengan Kejadian Stunting Pada Balita Usia 25-60 Bulan Di Kelurahan Kalibiru Depok Tahun 2012. Jakarta: Universitas Indonesia.

Depkes RI, 1999. Pedoman Operasional Program Imunisasi, Jakarta.

Fajariyah, R. N., \& Hidajah, A. C. (2020). JURNAL BERKALA EPIDEMIOLOGI. Jurnal Berkala Epidemiologi 8, p. 1. 
Kasim, E., Malonda, N., \& Amisi, M., 2019. Hubungan Antara Riwayat Pemberian Imunisasi dan Penyakit Infeksi dengan Status Gizi pada Anak Usia 24-59 Bulan di Kecamatan Ratahan Kabupaten Minahasa Tenggara.(Relationship Between History of Immunization and Infectious Disease with Nutritional Status in Children aged 24-59 Months in Ratahan Subdistrict, Southeast Minahasa Regency). JURNAL BIOS LOGOS, vol.9, no.1, p. 34-43.

Ni'mah, K., \& Nadhiroh, S. R., 2015. Faktor yang berhubungan dengan kejadian stunting pada balita. Media Gizi Indonesia, 10(1), p. 1319.

Permatasari, D. F., \& Sumarmi, S., 2018. Differences of born body length, history of infectious diseases, and development between stunting and non stunting toddlers. Jurnal Berkala Epidemiologi, 6(2), p. 182-191. https://doi.org/10.20473/jbe.v6i22018.182-191.

Riskesdas., 2013. Laporan Nasional Riset Kesehatan Dasar (Riskesdas Tahun 2013). Jakarta : Badan Penelitian dan Pengembangan Kesehatan Departemen.

World Health Organization, 2014. Global nutrition targets 2025: Stunting policy brief (No. WHO/NMH/NHD/14.3), World Health Organization. 